EASTERN REVIEW 2020, T. 9

\author{
Roman Savenkov \\ (iD https://orcid.org/0000-0002-1643-2444 \\ Voronezh State University, Voronezh, Russia \\ Department of Sociology and Political Science \\ e-mail: rvsaven@gmail.com
}

\title{
Public contestation practices in Russia in 2000-2020
}

\begin{abstract}
The article analyzes the influence exerted by the limitation of legal opportunities for public contestation in the 2000s on the scope of mobilization and the repertoire of public contestation practices. The term 'public contestation' is used to describe forms of individual and collective political activity focused on criticizing, denying and resisting the current government project, including by introducing alternative projects. The public contestation includes constructive actions of political actors not related to causing damage or disposing of political opponents. The paper is based on political and legal analysis and on some elements of event analysis. In the 2000s, the scale of public contestation on discursive and protest platforms was smaller than over the next decade, which did not create any needs for detailed regulation of such activities. At the same time, changes in political and legal opportunities in the electoral and party field were quite intense throughout 2000-2020. The most popular forms of public contestation were public events (in 2011-2018), as well as discursive activity on the Internet and in mass media (after 2018). During the above mentioned period, we see the biggest changes in legal opportunities in this field and increasing penalties for respective violations. The electoral field shows the pendulum dynamics: decreasing and increasing opportunities in 2000-2011 and 2012-2019, respectively. A meaningful factor of narrowing legal opportunities for public contestation is the potential financial, organizational and information support of public contestation practices by foreign entities.
\end{abstract}

Keywords: Contestation, political opportunity, protest, political party, non-government organization.

\section{Introduction}

Political processes in the contemporary world show the revival of collective political action and the decline of institutional political engagement in countries with various political systems. New forms of political self-expression extend 
the boundaries of politics beyond the narrow scope of electoral campaigns and party activity. Citizens of postindustrial states are getting more actively involved in politics than ever before and the forms of this involvement are changing (Inglehart, Welzel eds., 2005: 43). The global financial crisis of 2008, as well as new technical capabilities for public action, provoked 'global political awakening' and growth in the number of protests in both competitive (Van Vossole, 2015) and non-competitive regimes (The Legacy..., 2016).

Since the 2000s, the Russian Federation has been showing the wave dynamics of protest activity with demands for improving democratic institutions and practices. Some Russian social and political scientists recorded an increase in social and economic tensions and the scale of protests in 2011-2012, 2016-2017 for both socioeconomic and political reasons. A significant factor of all-Russian mobilisation of big-city residents discontented with the government was the social and political activity of Alexei Navalny who managed to create a broad network of regional organisations in 2017-2018 and conduct all-Russian protests with political demands. The government introduced considerable changes in legislation, limiting not only public protest events but also the demonstration of disagreement in other formats. The goal of our study is to analyse how the limitations of legal opportunities for public contestation in Russia in the 2000s influenced the scale of mobilisation and the repertoire of practices used for the expression of public discontent.

\section{Operationalisation}

The concept of 'contestation' was used by B. Jouvenel for the first time who meant the constant capability to articulate publicly the arguments against the policy pursued by legitimate authorities. According to the term's author, contestation is characteristic for democratic political regimes, i.e. for systems sensitive to criticism and able to discuss publicly the drawbacks and alternatives of the political agenda. According to Jouvenel, contestation includes only well-reasoned and substantiated disagreement. The subject of contestation is represented by ordinary citizens and spontaneous associations based on interests and affinities and who are eager to destroy the authoritarian instinct (Zhuvenel, 2011: 385) of the authorities who aim to increase their powers and extend the range of their influence under any political regime.

Institutionalised political opposition in the form of competing parties is one of the contestation tools in citizens' hands since it allows citizens to 'threaten' the ruling party with a prospect of losing votes at elections were they to implement a certain policy and with giving preferences to its rivals. However, the party and the electoral mechanism is not sufficient to have an impact on the government decisions: citizens' capabilities to oppose are now much broader and do not imply only the replacement of the ruling party or group (Jouvenel, 1966: 164). 
The notion of 'contestation' is more clearly defined by G. Ionescu who applies it to the analysis of non-competitive political regimes lacking the institute of party and political opposition. According to him, contestation means anti-system practices, the semi-legal and illegal actions of 'dissenters' based on fundamental ideological differences. Alternative (opposition) groups only criticise the authorities in force, since they are not able to win at sham elections and to become an opposition in the classic sense of liberal democracy (Ionescu, 1966). Later on, contestation practices in non-competitive regimes were considered as a mechanism for protest mobilisation (Beinin, Frédéric, 2013) and as a way to extend citizens' participation in conflict political processes (Jayasuriya, Rodan, 2007) and in decision-making processes (Katsaura, 2012; Harriss, 2010).

A broad interpretation of public contestation was given by R. Dahl who understood it as one of the parameters characterising the democratic or authoritarian nature of political regimes. According to Dahl, to "contest [...] means to make something the subject of dispute, contention, or litigation, and its most immediate synonyms are to dispute, challenge, or vie" (Dahl, 1971: 9). A substantial attribute of democracy is the continuous government's capability to respond to citizens' preferences. In order to provide this attribute, citizens should be able to: formulate their preferences, express their preferences to fellow citizens and the government through individual and collective actions, and have their preferences equally treated by the government. In Dahl's opinion, public contestation includes the whole variety of actions taken by citizens, professional politicians, political opposition aimed at the presentation of their disagreement with decisions being prepared or made by authorities or with their actions.

Following Dahl's tradition, A. Trantidis believes that "contestability is the necessary element of a democratic system that enables citizens to exert political influence and protect themselves from political domination" (Trantidis, 2016: 78). Studies in the history of the development of democracy in the USA and Great Britain allowed considering 'contestation' as a form of legal political engagement (Avril, Neem, 2015).

C. Tilly, S. Tarrow and D. McAdam use such a term as 'contention' and include political engagement and action in the concept of 'contentious politics'. The 'contentious politics' may be observed when ordinary citizens place demands on the government and conduct public campaigns by using existing forms of collective action and devising new ones, forming alliances with influential political actors, relying upon the existing capabilities of the political and legal framework and creating new ones, and combining institutional and non-institutional methods for advancing their demands. Contentious politics may be observed in the point of the intersection of three spheres of social life: competition, collective action and politics (Tilly, Tarrow, 2015: 8-10).

According to the above-mentioned scientists, public contestation (contention) includes such non-routinised types of political struggle as revolutions, social and 
nationalistic movements, industrial conflicts, wars, and actions of interest groups. At the same time, the category of 'contentious politics' does not include routinised political actions: electoral campaigns, parliamentary sessions, adoption of laws, administrative process, etc., though these events may accelerate it (McAdam, Tarrow, Tilly, 2001: 6). The 'contentious politics' may be triggered with changes in political capabilities and limitations allowing social groups deprived of access to representative democracy the institutions to create new resources for their actions or to use available ones in a new way. Such new resources may include organisations, ideas, as well as the technical means for coordination of collective actions.

Our understanding of the 'public contestation' phenomenon is based on the broad interpretation given by R. Dahl and applicable to various types of political regimes. Public contestation means forms of individual and collective political activity aimed at criticising, denying and resisting the projects being implemented by dominant actors, including by introducing alternative projects. In our opinion, public contestation includes the constructive actions of political actors not related to causing damage or the disposing of political opponents. Traditional and new digital types of public contestation create a wide range of opportunities for all stakeholders to communicate, specifying their stances and finding a compromise. As for political project, we understand it as an intellectual product formulating a vision of the future, a goal and program of long- and short-term actions.

The category of 'public contestation' does not include aggressive non-conventional forms of resistance and protest - destructive actions blocking communications and conflict resolutions. At the same time, the full cycle of contesting actions may include the individual practices of non-conventional actions aimed at attracting public attention to particular problems and forcing the parties to open a dialogue. Public contestation is considered as a special case of a political conflict playing a positive role in the political system.

On the one hand, public contestation practices ensure that opinions of parties not represented in the official discourse are taken into account while specific decisions are made, and, on the other hand, they shape a system of relations between the government and the society, where the government will keep an impetus and a capability to respond to citizens' preferences. The diversity of practices and efficiency of public contestation depend on the political regime, political and legal opportunities and established socio-cultural traditions and the forms of dialogue between the government and the society.

At the first stage, we focus on conventional practices of public contestation used by citizens, political parties and movements contesting government projects. The public discussion of political projects is arranged on various political and administrative platforms. As J. Habermas said, the modern public sphere covers various platforms for more or less discursive disputes and the expression of opinions (Habermas, 2017: 13, 18). In this paper, we will discuss discursive, 
protest and electoral platforms. They differ in the status of interaction participants and the scale of mass mobilisation. The contestation of political projects may switch from one platform to another, increasing the number of its supporters and opponents, finding new arguments and counter-arguments.

The most available and socially approved contestation method is discussion. Contestation on the discursive platform is carried out by citizens verbally (or with the use of texts or images) without meaningful political and legal implications for a project being contested. The articulation of citizens' opinion is considered by them as a non-conflictive way of interaction with authorities and thus not causing any retaliatory sanctions. Participation in discussions does not require any special skills, knowledge or status. Discursive platforms represent an assembly point for all possible opinions and estimates with regard to political projects.

Brand new opportunities for public contestation have been created by the rapid development of the Internet, the invention of technical capabilities allowing a mass audience to create and distribute information content. Owing to online communications, the public space has become much more liberal and turned into a platform for voluntary, informed and open dialogue based on horizontal links and participation equality; allowing citizens to have a 'soft impact' on the government. The specific character of the protest platform manifests itself in the offensive form of actors' interaction, in the confrontational way of influencing political decisions through publicly voicing demands and persuading government actors to satisfy them. The protest behaviour represents a form of collective action where the activity of citizens is coordinated and aimed at achieving a common goal (Sztompka, 2012: 208-209). The protest platform is more norm-regulated than the discursive but less than the electoral one.

Contestation of the protest platform may be reactive, protective (when new projects disrupting the status quo are contested) and active (when the status quo is contested, demands to change political rules are made and capabilities related to the political leverage of outsiders are extended). Active contestation provides the basis for establishing a new political project. The protest contestation may be either loyal (participants acknowledge the legitimacy of authorities and propose to right injustice with their decision) or confrontational (contestation subjects do not acknowledge the legitimacy of authorities, do not believe in their just decision in this matter, and therefore demand political changes and reforms).

The electoral platform of public contestation resembles the discursive (there is a dispute, a conflict) and the protest one (there are public events with a call to vote for or against a candidate or a party). The contestation results in voting for or against candidates and their projects or the electors' refusal to vote. The results of contestation have legal implications, and allow the assessing of the popularity and vigour of candidates' arguments and projects, as well as consolidate the party and political balance of power until the next election. 
The electoral platform of public contestation is conventional and the least costly for all citizens having the right to vote. Voting represents the mass behaviour of electors who act on their own, but the results of this action have a macro-social impact (Sztompka, 2012: 202-203). The autonomy of citizens' actions encourages candidates to articulate new ideas, create their own alternative political projects, 'snatch away' interesting political innovations from their competitors with a view to winning over potential voters. Electoral programs represent the definitive variant of political projects aggregating social problems. Government authorities, incumbents are especially sensitive to citizens' opinions and their disagreement on the electoral platform, since ignoring the electors' stance may result in losing their votes (Gluhova, 2020: 24) irrespective of the regime type.

The range of public subjects on the electoral platform is limited by the laws: normally, these are political parties, electoral blocs, social movements. Electoral support is a measurable and predictable indicator, which allows the estimation of the capabilities of an opposition party: the vigour of its arguments and the ability to mobilise its supporters and sympathisers.

At the second stage, we discuss changes in laws and regulations, regulating practices of public contestation on discursive, protest and electoral platforms with the use of political and legal analysis. The legal component implies the analysis of laws and regulations for the compliance of the government's decisions and actions enshrined in them with the constitution. The political component involves the analysis of the political orientation of the government's decisions enshrined in laws and regulations that may be aimed at solving problems in favour of either all citizens and social development or individual persons or groups (Nisnevich, 2011).

\section{Public contestation practices in Russia in 2000-2020}

The development of e-democracy is transferring politics to an online space and decreasing the importance of traditional formats of relations between governmental and public institutions (Volodenkov, 2020: 8), while the importance of the discursive platform for public contestation is growing. The conventional form of public contestation in today's Russia is an online petition implying an application, an appeal or a complaint from a citizen or a group of persons to local, regional or federal authorities filed with the use of special portals. The main advantage of online petitions is their availability, each citizen's opportunity to support a proposed petition or create a new one (Porshnev, Lyachina, 2018: 118). In 2013, the Presidential Decree created a portal called Russian Public Initiative (ROI). Petitions may be supported with the signatures of Russian citizens aged over 18 registered on the Gosuslugi (Government Services) portal. A petition that collects more than 100,000 signatures should be transferred to an expert group for consideration (Rossijskaya..., 2020). 
Over seven years (by July 2020), the portal has been used to file 17,371 petitions. Only half of the 36 initiatives transferred for consideration collected the required number of votes, while the rest were considered by authorities without achieving the threshold of 100,000 signatures (Vidyasova, Tensina, 2017: 60). In spite of the fact that 18 initiatives have been approved (less than $1 \%$ of all the petitions filed), the number of initiatives that caused a public outcry and collected the required number of signatures is next to none. The observers are sceptical about the contesting potential of ROI and present it as a public manifestation of the traditional Russian institution of 'formal replies' (Shul'man, 2014: 129). Therefore, Russian citizens got a formal opportunity to advance constructive ideas and projects for the government.

An influential subject of public contestation on the discursive and protest platforms is a movement headed by Alexei Navalny. Video messages from this opposition politician criticizing representatives of the political and economic elite forced the latter to respond in the media space and publish their own video responses. The film Don't Call Him "Dimon" (2017) made by the AntiCorruption Foundation received 36 million views on the Internet and provoked protests in major cities in March 2017. The film A Palace for Putin was watched by 85 million people, and on January 23 major Russian cities saw confrontational unauthorised protests demanding the politician, who had been arrested for violating the terms of a suspended sentence in a 2014 criminal conviction, be released.

After a series of federal protests (March 2017-May 2018), A. Navalny's organizations in regions conducted a strong and offensive information campaign aimed at revealing deficiencies and mistakes in the actions of authorities and members of the United Russia party. Key awareness-building efforts in 2018-2019 were made online, on the official website of regional headquarters and on popular social networks. Navalny's network structure is actively disputing both federal and local problems and seeking support from the electorate of other parties during elections. Navalny conducts investigations and publishes the respective findings, but cannot propose any alternative political projects that would gain support from large segments of voters since he is banned from elections due to an outstanding conviction and cannot register his own political party.

The analysis of public discussions on the Internet suggests that the institution of public criticism has not been developed in Russia yet. It requires not only enshrining the right to fair and correct public criticism in laws and moral codes but also turning it into a natural and everyday practice. The institutionalisation of public criticism will be promoted by the authorities' systematic response to the critical feedback from the general public (Timofeeva, 2020).

Public contestation on the protest platform in Russia was characterised by wave dynamics: Period I (2000-2011) - the growth in income of most citizens and low protest activity (so-called "fat 2000s"), Period II (December 2011-2020) 
- growth in protest activity at the national and local levels, articulation of both socioeconomic and political demands.

In the 2000s, the protest activity of Russian citizens was not large-scale and was characterised by fluctuating dynamics. Before 2005, the major portion of protests was constituted by labour strikes and political mobilisation was generally caused by economic problems (Graeme, 2011). The largest protests were represented by the collective actions of pensioners against the government's project of "benefits monetisation" in January-February 2005 that mobilised over 430,000 people across Russia (Pod'yachev, 2012). The contestation resulted in the indexation of pensions and the increase of monetary compensations paid by regional authorities in some subjects of the Russian Federation.

Starting from 2004, there has been an upturn in public contestation in the political sphere, on the part of professional politicians, extra-parliamentary opposition: protests were organised by the National Bolshevik Party (banned in Russia), the Vanguard of Red Youth, the United Civil Front (G. Kasparov), etc. From late 2005 to 2008, the Other Russia coalition held street demonstrations called the Dissenters' March. Starting from 2009, the format of protests has changed: they were timed to coincide with the 31 st day of each month symbolising the protection of Article 31 of the Russian Constitution concerning the right to assemble peacefully. Protesters demanded V. Putin's resignation, but did not have the grassroots support and, trying to gain the media attention, provoked the use of force by law enforcement agencies (Kertman, Miryasova, 2010: 109-112).

In general, the public contestation on the protest platform in 2000-2011 was conducted with the use of traditional protective actions, without the large-scale making of political demands and without demands to change the established system of relations between the government and the society. The opposition only tactically responded to mistakes and the corrupt practices on the part of authorities.

A new stage of the upturn in public contestation on the protest platform started in late 2011, with a huge wave of large-scale protests in the major cities of Russia that was provoked by media reports on violations in vote counting at the elections of deputies for the State Duma on December 4. According to organisers, the collective actions were participated in by over 100,000 people. In 2012, demands for a vote recount and the resignation of $\mathrm{V}$. Churov (head of the Central Election Commission) advanced in 2011 were replaced by demands for the re-election of deputies and the resignation of V. Putin (Volkov, 2012: 73).

The large-scale collective actions in Moscow on December 10 and 24 showed that citizens and authorities are able to interact via collective public actions, in a civilized form, without violence and aggression (Doklad..., 2012: 6). The movement For Fair Elections marked a short-term shift in citizens' concern from the personal space to the protection of public interests. The protest movement turned into a kind of political project, since protesters did not turn to the protection of particular interests, but actualised a civil request for political democracy and 
fair political procedures, which gave rise to a number of metaphors concerning the 'awakening of civic awareness'. The fact that protest leaders were elected to the Coordination Board in autumn 2012 did not help to expand the public support of the aforementioned demands. However, in terms of scale, it was one of the largest movements in contemporary Russia.

From 2015-2018, there was some increase in the number of public protests in Russia. The increase in the number of all-Russian protests, starting from July 2018, was mainly organised by the largest parliamentary Communist Party of the Russian Federation (CPRF) which was mobilising the opponents of the government's project of pension reform. These acts were aimed at an attempt to initiate a referendum procedure and cancel the plans to increase the retirement age. The Central Election Commission of Russia twice refused to hold the referendum proposed by the CPRF. The CPRF was the most active organiser of protests related to socioeconomic and political issues (Savenkov, 2019).

The second influential subject of public contestation on the protest platform in 2017-2018 was A. Navalny's movement. In 2017-2018, Navalny established a broad network of regional organisations in all major cities of Russia. Contemporary Russia did not have any political movements (except for political parties) which were able to hold long-term all-Russian protests. The federal-level of protest events and the high popularity of Navalny's video content allows us to consider his movement as an influential political organisation with a stable structure and an established (though small) core of supporters. According to Kommersant, the unauthorised protests on 23.01.2021 demanding the release of A. Navalny were held without a formal leader in more than one hundred Russian cities and towns (Protesty 23.01. Glavnoe, 2021).

The third subject of public contestation was represented by spontaneous groups of citizens formed with regard to specific problems, without any alternative political projects. The all-Russian movement of heavy-duty-truck drivers "Anti-Platon" (November 2015) and the march to Moscow organised by Krasnodar farmers on tractors (August 2016) were quite unexpected for the Russian authorities. The "Anti-Platon" protesters published video addresses to V. Putin requesting the abolition of "Platon". Negotiations with the federal authorities resulted in a temporary concession: the reduction of fares for trucks. May 2017 saw a series of large-scale collective protests in Moscow against a renovation program (providing for the demolition of old houses and the resettlement to new houses in different districts). Traditional rallies had from 4,000 to 20,000 participants. In 2018-2020, there were high-profile protests in Volokolamsk and Kemerovo (spring 2018), Khabarovsk (2020). The protesters in Volokolamsk endeavoured to persuade V. Putin to close a landfill site in their town as he 'closed' the landfill in Balashikha in June 2017. A fire accident in a cinema in Kemerovo, which resulted in the death of 41 children, provoked a spontaneous hours-long rally in the city. The protesters demanded truthful information on the tragedy, penalties to those 
responsible for the accident and the resignation of Aman Tuleyev (governor of the Kemerovo Oblast in 1997-2018). There is a weekly campaign in Khabarovsk against the detention of Khabarovsk Krai governor S. Furgal (LDPR) who had been accused of serious crimes allegedly committed in 2004-2005.

A series of protests called "For Fair Elections" was held in Moscow in July 2019. The protesters demanded that candidates removed due to complaints against signatures and other collected documents which had had to be admitted to elections to the Moscow City Duma. The authorised protest on June 20 and unauthorised protests on June 14 and 27 were participated in by about 20,000 and 3,000-5,000 Muscovites respectively. The last unauthorised protest ended with the violent arrest of more than 1,000 people. The arrests of organisers and leaders prior to the protests did not demoralise protesters and demonstrated the potential of decentralised social structures. The Muscovites' protective protest contestation did not make the authorities admit protest candidates to the elections or give clear explanations to the 'non-system opposition'. Furthermore, the Muscovites' civic stance is not converted to political dividends or transformed into the large-scale social movement (Akciya za chestnye..., 2019).

In general, most social and economic protests in Russia were local, not large-scale, all-Russian ones and demanded only to solve specific non-political problems. The protesters emphasised their loyalty to V. Putin and asked him to protect their corporate interests, which limited their capabilities to mobilise supporters and diminished the moral support from non-involved citizens. Regional authorities invited the action organisers to dialogue and coerced them into compromise, while law enforcement agencies prevented campaigns on legitimate grounds. The political protests were held in large cities and towns (A. Navalny movement, Ivan Golunov supporters, "For Fair Elections") and involved a small fraction of unsympathetic urban dwellers.

As for the federal electoral platform, in 2000-2020 there was no considerable public contestation. The State Duma was dominated by United Russia, while the opposition consisted of the Communist Party of the Russian Federation, LDPR and A Just Russia. The opposition parties did not establish coalitions and often competed with each other. Other parties could not clear the threshold and were not approved for the allocation of deputy seats based on election results. The number of parties having the right to field candidates for elections decreased from 46 in 2000 to 7 in 2011 and then increased to 78 in 2016; in 2020 it amounted to 42.

Therefore, the public contestation on discursive and electoral platforms has not originated any constructive alternative projects nor any rewarding experience of dialogue between the government and society. The protest activity of citizens during the period in question was of a local and protective nature and was aimed at non-political concessions from the government. The political protests in 2011-2012 forced some liberalisation of the political system, but clashes with the police resulted in the instigation of criminal proceedings against about 20 protesters. 


\section{Dynamics of legal opportunities for public contestation in Russia in 2000-2020}

We distinguish two periods in the transformation of legal opportunities for public contestation: Period I - 2000-2011 and Period II - 2011-2020, as differing by the intensity and scale of public contestation, as well as by the intensity of changes in respective legal opportunities arranged by government authorities. It is generally agreed among social and political scientists that the first period of economic growth was characterised by a lower scale of public contestation on discursive and protest platforms than the following decade, which did not create any needs for detailed regulation of such activities. At the same time, changes in the political and legal opportunities on the electoral platform were intense throughout the period. During the second period (2011-2020), the number of public contestation actions increased, which created the need for the more detailed regulation of protest rules. The political sphere, by contrast, showed the formal regulatory relief with regard to the potential participants of the electoral platform.

During the first period, there were three minor amendments made to the federal law No.54-FZ "On Rallies, Meetings, Demonstrations, Marches and Picketing" dated 19.06.2004 (hereinafter referred to as No. 54-FZ): on December 8, 2010, February 7 and December 8, 2011 (54-FZ).

As for changes in the institutional opportunities for political contestation on the electoral platform (laws on elections and parties), they are, by contrast, characterised by the toughening of requirements. In 1998, a notion of "political public association" was included in the law "On Public Associations" and was defined as

a public association, the charter of which must provide for participation in the political life of the society through exerting influence on the shaping of citizens' political will, participation in elections to the bodies of state power and local self-government by means of nominating candidates and organising their electoral campaign (Borisov et al., 2015: 57).

The federal law No.95-FZ "On Political Parties" dated 11.07.2001 vested parties with the exclusive right to field candidates for federal and regional elections. Parties could be only all-Russian ones and had to have at least 10,000 members and branches at least in half of all subjects of the Russian Federation. The law also introduced the government financing of political parties winning at least $3 \%$ of votes at elections to the State Duma.

In 2002, laws on elections were amended: instead of collecting signatures, while registering candidates, it was made possible to deposit an electoral pledge, the nomination by a group of electors was abolished, and only the self-nomination procedure was kept for non-party contenders. In September 2004, the requirement 
of the minimum membership of political parties was increased fivefold - from 10,000 to 50,000 members. At the same time, the direct election of heads of federal subjects of Russia was abolished, and in 2005 elections to the State Duma were completely transferred to the proportional system with a seat allocation threshold of $7 \%$. In 2005, electoral blocs were abolished, non-party public associations were deprived of their right to send observers to polling stations, rules for registration based on signatures were toughened, and two single voting days per year were introduced.

In 2006, the "none of the above" field and the minimum voter turnout requirement were abolished, the nomination of party members from lists of other parties and the criticising of rivals on TV were prohibited, and additional limitations of the right to be elected were introduced. In 2009, the electoral pledge was abolished, and non-party public associations lost their right to field candidate lists at municipal elections (Borisov, Korgunyuk, 2015: 57-61). As a result, at the end of the 2000s, the opportunities for party and political contestation were limited considerably, while opposition parties were disoriented and weakened.

Therefore, during the first period, the reduction of political and legal opportunities for public contestation was about institutionalised forms - activities of political parties. Amendments in laws on elections and parties reduced the number of parties able to be institutionalised participants of public contestation in the political sphere. Such actions cannot be interpreted as repressions, but they significantly decreased the opposition's opportunities to mobilise its supporters, to contest political projects, to secure the legal implications of its actions.

Government authorities did not virtually amend laws on contestation on discursive and protest platforms (public criticism, public events, activities of NPOs). It is related to the marginal impact of public self-organisation and activity on the intensity of public contestation and political competitiveness in general. Even large-scale protest events of the 2000s did not contest the established authority distribution system. The authorities could demobilise protests through the partial satisfaction of contestation subjects' demands.

The second chronological period started with a tidal wave of large-scale protests in major Russian cities in late 2011, which was provoked by reports on large-scale vote-counting violations during the elections of deputies for the State Duma on December 4. The scale of collective actions of 'angry city-dwellers' in 2011-2012 had a twofold impact on the political system. On the one hand, the protests in the capital were interpreted by the authorities as a failure in established political and electoral practices, which resulted in a reshuffling in the Russian Presidential Executive Office. In March 2016, the new composition of the Central Election Commission was announced: chaired by Ella Pamfilova, a former chairwoman of the Presidential Council for Civil Society and Human Rights. On the one hand, it restored some opportunities for citizens' electoral influence on political decisions, but on the other hand, the civic life started to show the 
transformation of such political and legal opportunities as rules for holding public events, activities of NPOs taking part in politics, and public discussion rules.

The most numerous amendments were made to No.54-FZ in the summer of 2012. The organiser is obliged to take measures to limit the number of event participants. Public event participants may not conceal their faces, including through the use of masks, means of disguise or other items specially intended to make them more difficult to identify. Regional authorities are obliged to establish 'Hyde Parks', places for collective discussion of socially important issues and the expression of public sentiments. In 2012, the administrative penalties for the violation of rules for holding public events outlined in the Code of Administrative Offences were increased. Moreover, new articles were introduced with sanctions for the violation of public contestation rules.

These amendments constituted the basis for an appeal filed by a group of deputies of the State Duma to the Constitutional Court of the Russian Federation since the innovations "contain unjustified and excessive limitations of the right to free peaceful assembly not caused by constitutionally recognised goals and entrenching upon the essence of this constitutional right" (Postanovlenie..., 2013). The Constitutional Court of the Russian Federation generally recognised most innovations as corresponding to the Constitution but interpreted them for the benefit of citizens, their right to peaceful assembly, rallies, meetings, demonstrations, marches and picketing.

In the summer of 2014 , criminal liability was introduced for repeated violations of rules for organising and holding of public events. Violators may face up to five years of imprisonment or a fine of up to RUB 1,000,000 (V. Putin uzhestochil..., 2014). In 2018, a penalty was introduced for the encouragement of minors in participating in unauthorised public events - up to RUB 50,000, or an administrative arrest for 15 days. A federal law adopted in December 2020 states that public events may be represented by any integrated large-scale simultaneous stay and (or) movement of citizens in public places aimed at the expression or generation of opinions, the advancement of demands regarding various political, economic, social, cultural and foreign policy issues (497-FZ, 2020). It has constrained single-person protests not requiring the approval by authorities.

Therefore, according to lawyers, the laws in force and law enforcement practice with regard to the freedom of public assembly are quite restrictive (Salenko, 2019: 52).

Non-profit organisations that may potentially be the subjects of public political contestation were also legally regulated. On July 20, 2012, federal law No.7-FZ "On Non-profit Organisations", dated 12.01.1996, was supplemented with a notion of "non-profit organisation serving as a foreign agent" - a Russian NPO receiving money from foreign states and participating in political activity in Russia. The political activity meant political actions focused on affecting the government authorities' decisions aimed at changing their public policy, and on 
shaping the respective public opinion (121-FZ, 2012). Later, the notion of 'political activity' in this law was changed several times and was eventually interpreted quite broadly in December 2019. In accordance with the law, the political activity includes public events, participation in elections and referendums, public appeals to government authorities, dissemination of opinions about government authorities' decisions and policy, shaping social and political views, etc. (179-FZ, 2016).

Russian NPOs serving as foreign agents have to report more frequently and indicate their status while publishing their materials. The law provides for introducing a register of non-profit organisations serving as foreign agents (7-FZ, 1996: art. 24, 32). The Federal Law issued in 2014 allows the Russian Ministry of Justice to include Russian NPOs in the register of foreign agents at its own discretion (121-FZ, 2014).

The federal law "On Sanctions for Individuals Violating Fundamental Human Rights and Freedoms of the Citizens of the Russian Federation" adopted in December 2012 empowering federal authorities to suspend activities of non-profit organisations taking part in political activity in the territory of Russia and receiving money and other property of U.S. citizens (organisations) on a non-reimbursable basis or implementing projects, programs or conducting other activities posing a threat to the interests of the Russian Federation. The activity of the organisation may be resumed if it refuses to receive money from U.S. citizens (272-FZ, 2012: art. 3). In December 2018, some important amendments were made regarding the participation of foreign NPOs in the electoral process and the organisation of referendums:

activities of a foreign or international non-governmental organisation posing a threat to the foundations of the constitutional system of the Russian Federation, its defensive capacity or national security, including those promoting or preventing the nomination of candidates, candidate lists, the election of registered candidates, the advancement of referendum initiatives or the holding of referendums, the achieving of certain results at elections or referendums, may be recognised as undesirable in the territory of Russia (555-FZ, 2018).

In spring 2015, the Federal Law on so-called 'undesirable' foreign organisations in Russia was adopted. The law stipulates that any foreign or international, but only non-governmental organisation "posing a threat to the foundations of the constitutional system of the Russian Federation, its defensive capacity or national security" may be recognised as such (signed by Putin, 2015). In May 2015, some amendments were made to the Criminal Code of the Russian Federation introducing criminal liability for control over activities of foreign or international non-governmental organisations recognised as undesirable in the territory of Russia (129-FZ, 2015). In the summer of 2020, court hearings began on the first criminal proceedings against Anastasia Shevchenko, a member of the board of Open Russia, UK, recognised as an undesirable organisation (Ya ne ponimayu, 2020). The proceedings have not yet finished. 
A number of laws and regulations adopted in the spring of 2019 curtailed the freedom of public discussion and criticism. Amendments made on March 18, 2019 , prohibited distributing "indecent information insulting human dignity and public morality, expressing obvious disrespect for the society, state, official national symbols of the Russian Federation, Constitution of the Russian Federation or the government authorities of the Russian Federation" on the Internet (30-FZ, 2019). The law prohibits the distribution of information "containing calls for mass riots, extremist activities, participation in mass (public) events violating the established procedures, as well as misleading socially significant information distributed as trustworthy reports" on the Internet (149-FZ, 2019: Article 15.3).

According to amendments made to the Code of the Russian Federation on Administrative Offences, the distribution of deliberately misleading socially significant information as trustworthy reports posing a threat of personal injury, property damage, mass disorder is punishable by an administrative fine (Kodeks..., 2001: Article 13.15). The law also prescribes the blocking of resources publishing fake news. If a media provider does not remove misleading information upon request from Roskomnadzor, the access to the website will be restricted.

Amendments made to the Federal Law "On Mass Media" in December 2019 introduced a notion of 'a mass provider serving as a foreign agent'. Mass media having the 'foreign agent' status and receiving money from foreign states are obliged to meet the requirements applied to NPOs recognised as "serving as foreign agents" (46-FZ: art. 1). A law adopted in December 2020 provided for the recognition of citizens (individuals) as serving as foreign agents if they are involved in public activities in Russia on behalf of foreign states and financed from abroad (481-FZ: art. 2').

Therefore, some strengthening of the regulation of public contestation practices on discursive and protest platforms and the toughening of sanctions against rule-breakers can be observed. The key argument for developing a strategy focused on the 'reduction' of opportunities to hold public events was the protection of public order. According to legislators, Russian non-profit organisations funded from abroad and some foreign non-profit organisations pose a serious threat to the constitutional system. Political demands increase the polarisation of citizens and may result in spontaneous (or planned) mass riots. The discourse of actors supporting the 'reduction of opportunities' shows protests as a political technology that may be used by shady politicians and foreign governments to destabilise the political system and act against the interests of Russian society. The second argument was the incompetence and credulity of ordinary citizens taking part in public events under the influence of manipulative technologies used by 'rogue politicians'. The third argument was the need to ensure the security of protest organisers themselves. And the fourth one was the enforcement of the rights and interests of other citizens who may be incommoded by public actions (Patrushev ed. 2016: 222-225). 
In contrast, the political sphere shows increasing opportunities for the activity of political parties. Under the influence of protests in December 2011, Dmitry Medvedev, the then President of Russia, came up with proposals to 'liberalise' the laws on parties and elections. In 2012, the minimum membership of political parties was decreased from 40,000 to 500 , while all registered parties were dispensed from signature collection; annual reports were replaced with triennial ones; parties not taking part in elections have to be dissolved not after five, but after seven consecutive years of such non-participation (28-FZ). Moreover, gubernatorial elections were restored, with the introduction of the 'municipal filter', a need to collect signatures of regional and municipal deputies in furtherance of particular candidates, which constrained the registration of protest candidates. The elections of deputies for the State Duma in 2014 saw the restoration of a mixed system, five-per cent threshold, and the "none of the above" field at municipal elections by the decision of regional legislators. Laws on elections adopted in 2012 introduced the single voting day - the second Sunday of September (Borisov et al., 2015: 57).

However, the increase in the number of parties (42 in November 2020) has not resulted in any changes in the political landscape of the State Duma after the elections held in 2016 or in any considerable growth of representation of non-parliamentary political parties in regional legislative bodies (Gayvoronskiy, 2018). A massive public outcry was caused by the victories of CPRF and LDPR candidates at the gubernatorial elections in 2018, but in general, it did not change the rules and results of public contestation on the electoral platform.

Therefore, after 2012, public contestation on the protest platform became a common, but not a mass phenomenon. The Federal Assembly of Russia introduced many restrictions for public event organisers and for mass media. At the same time, the protest activity was concentrated in major cities and was not large-scale in smaller cities and towns (Grazhdanskoe..., 2013: 401). The specific 'institutionalisation' of protests initiated the transformation of the structure of political and legal capabilities: on the one hand, the period in question saw the reduction of opportunities for public contestation on discursive and protest platforms. At the same time, the limitation of opportunities for public contestation by NPOs providing for the mass mobilisation of citizens, political demands and reliance on foreign funds promoted the launch of government programs focused on the support of loyal civil initiatives not related to public contestation. The largest government support is received by volunteer organisations and projects.

The strategy of federal authorities with regard to public contestation practices was focused on adding greater punitive measures for unauthorised public actions, and on the limitation of opportunities for political activity of NPOs and mass media funded from abroad. The simplification of the procedure used for the registration of political parties increased their number, but did not change the political landscape in the State Duma and regional legislative bodies. During the period in question, 
parliamentary parties contested the policy pursued by the government but did not propose alternative projects and teams.

As a result, citizens are giving up on using the protest platform to contest political issues. According to opinion polls, $80 \%$ of Russians are willing to take part in elections (both residents of major cities and other settlements). To a large extent, this willingness is declarative, since the practice shows that this right is exercised only at federal elections, while the turnout at local elections does not exceed $20-30 \%$. The second acceptable type of social and political activity is the scrutiny at elections (it was mentioned by about $15 \%$ of respondents). The willingness of people for other types of social and political activity is less than $4-5 \%$. The least appealing ones are participation in party work, as well as radical forms of protest. "Any mass action is now perceived as a political and, therefore, prohibited one", says Mikhail Vinogradov, the head of the Petersburg Politics Foundation. "The society received a series of clear messages regarding the readiness to crack down on any actions, even authorised ones. Therefore, the willingness for such actions requires larger radicalism" (Rossiyanam..., 2019).

\section{Conclusion}

Public contestation is a legal form of criticising and counteracting the current government's project by citizens and professional opposition. The main advantage of contestation is an opportunity to introduce alternative ideas and projects. We believe that public contestation includes constructive actions of political actors not related to causing damage or disposing of political opponents. Public contestation may be carried out on discursive, protest and electoral platforms. The expansion of public contestation on the Internet and the increase in the number of protests in Russia after 2011 resulted in the adoption of a number of restrictive laws and the subsequent decrease in the number of large-scale protests. Unsympathetic citizens are looking for new legal and non-legal opportunities to express their stance on the discursive and protest platforms, in loyal and confrontational forms. At the same time, we see some liberalisation of the laws on elections and parties with the formal simplification of party formation and participation in elections. However, citizens feel suspicious about opportunities for public contestation on the electoral platform. To keep the political system stable, citizens should retain real opportunities to criticise and contest the authorities' decisions in constructive and legal form. 


\section{References}

Aktsiya za chestnye vybory v Moskve. Glavnoe. 2019. RBC, 24 June. https://www.rbc.ru/ politics/27/07/2019/5d3c8a7c9a7947630f84424a (accessed 22.06.2020).

Avril, E., Neem, J. 2015. Democracy, Participation and Contestation: Civil society, governance and the future of liberal democracy. London: Routledge.

Beinin, J., Frédéric, V. 2013. Social Movements, Mobilization, and Contestation in the Middle East and North Africa. Stanford, California: Stanford University Press.

Borisov, N., Korgunyuk, Y., Lyubarev, A. (eds.). 2015. Partiynaya reforma i kontrreforma 2012-2014 godov: predposylki, predvaritel'nyye itogi, tendentsii. Moskva: KMK.

Dahl, R. 1971. Polyarchy: Participation and Opposition. New Haven: Yale University Press.

Doklad o deyatel'nosti Upolnomochennogo po pravam cheloveka v Rossijskoj Federacii za 2017 god. 2018. Rossijskaya gazeta. 17 April, https://rg.ru/2018/04/16/dokladsite-dok.html (accessed 22.06.2020).

Doklad o sostoyanii grazhdanskogo obshchestva v Rossijskoj Federacii (2011 g.). 2012. Moskva: Obshchestvennaya palata RF.

Federal'ny zakon 121 “Ob inostrannyh agentah”, 2014. RIA-Novosti, 16 July, https://ria. $\mathrm{ru} / 20140616 / 1011656413 . \mathrm{html}$ (accessed 22.06.2020).

Federal'ny zakon ot 12.01.1996, 7-FZ “O nekommercheskih organizaciyah”, http://www. consultant.ru/document/cons_doc_LAW_8824/(accessed 22.06.2020).

Federal'ny zakon ot 19.06.2004 №54-FZ "O sobraniyah, mitingah, demonstraciyah, shestviyah $i$ piketirovaniyah", http://www.consultant.ru/document/cons_doc_ LAW_48103/(accessed 22.06.2020).

Federal'ny zakon ot 27.07.2006, 149-FZ “Ob informacii, informacionnyh tekhnologiyah io zashchite informacii”, http://www.consultant.ru/document/cons_doc_LAW_61798/ (accessed 22.06.2020).

Federal'ny zakon ot 2.04.2012, 28-FZ “O vnesenii izmenenij v Federal'nyj zakon ot 11.07.2001 №95-FZ O politicheskih partiyah”, http:/www.consultant.ru/document/ cons_doc_LAW_127961/(accessed 22.06.2020).

Federal'ny zakon ot 20.07.2012, 121-FZ "O vnesenii izmenenij $v$ otdel'nye zakonodatel'nye akty Rossijskoj Federacii $v$ chasti regulirovaniya deyatel'nosti nekommercheskih organizacij, vypolnyayushchih funkcii inostrannogo agenta", http:// www.consultant.ru/document/cons_doc_LAW_132900 (accessed 22.06.2020).

Federal'ny zakon ot 28.12.2012, 272-FZ "O merah vozdejstviya na lic, prichastnyh $k$ narusheniyam osnovopolagayushchih prav i svobod cheloveka, prav i svobod grazhdan Rossijskoj Federacii”, http://www.consultant.ru/document/cons_doc_ LAW_139994/(accessed 22.06.2020).

Federal'ny zakon ot 23.05.2015, 129-FZ "O vnesenii izmenenij v otdel'nye zakonodatel'nye akty Rossijskoj Federacii”, http://www.consultant.ru/document/cons_doc_ LAW_179979/ (accessed 22.06.2020).

Federal'ny zakon ot 9.03.2016, 66-FZ “O vnesenii izmenenij v otdel'nye zakonodatel'nye akty Rossijskoj Federacii o vyborah i referendumah $i$ inye zakonodatel'nye akty Rossijskoj Federacii”, http://www.consultant.ru/document/cons_doc_LAW_194895/ (accessed 22.06.2020). 
Federal'ny zakon ot 2.06.2016, 179-FZ “O vnesenii izmenenij v stat'yu 8 Federal'nogo zakona Ob obshchestvennyh ob'edineniyah i stat'yu 2 Federal'nogo zakona O nekommercheskih organizaciyah", http://www.consultant.ru/document/cons_doc_ LAW_198862/ (accessed 22.06.2020).

Federal'ny zakon ot 27.12.2018, 555-FZ “O vnesenii izmeneniya v stat'yu 3.1 Federal'nogo zakona $O$ merah vozdejstviya na lic, prichastnyh $k$ narusheniyam osnovopolagayushchih prav i svobod cheloveka, prav i svobod grazhdan Rossijskoj Federacii”, http:// www.consultant.ru/document/cons doc_LAW_314692/(accessed 22.06.2020).

Federal'nyj zakon ot 18.03.2019, 30-FZ “O vnesenii izmeneniya v Federal'nyj zakon Ob informacii, informacionnyh tekhnologiyah $i$ o zashchite informacii”, http://www. consultant.ru/document/cons_doc_LAW_320400/(accessed 22.06.2020).

Federal'ny zakon ot 2.12.2019, 426-FZ “O vnesenii izmenenij v Zakon Rossijskoj Federacii O sredstvah massovoj informacii i federal'nyj zakon Ob informacii, informacionnyh tekhnologiyah i o zashchite informacii", http://www.consultant.ru/document/cons doc_LAW_339109/(accessed 22.06.2020).

Federal'ny zakon ot 30.12.2020, 481-FZ “O vnesenii izmenenij v otdel'nye zakonodatel'nye akty Rossijskoj Federacii v chasti ustanovleniya dopolnitel'nyh mer protivodejstviya ugrozam nacional'noj bezopasnostihttp", //publication.pravo.gov.ru/ Document/Text/0001202012300001 (accessed 22.01.2021).

Federal'nyj zakon ot 30.12.2020, 497-FZ "O vnesenii izmenenij v Federal'nyj zakon O sobraniyah, mitingah, demonstraciyah, shestviyah i piketirovaniyah”, https://rg. $\mathrm{ru} / 2021 / 01 / 11 /$ sobraniya-dok.html (accessed 22.01.2021).

Gayvoronskiy, Y. 2018. Faktory nacionalizacii partijnoj sistemy sovremennoj Rossii. Polis. Politicheskie issledovaniya 1, pp. 45-61.

Gluhova, A. 2020. Vnutripoliticheskaya povestka dnya kak faktor edinstva sovremennoj Rossii. Voronezh: Izdatel'sko-poligraficheskij centr "Nauchnaya kniga".

Graeme, R. 2011. The Politics of Protest in Hybrid Regimes. Managing Dissent in Post-Communist Russia. Cambridge: Cambridge University Press.

Greene, S. 2014. Moscow in Movement: Power and Opposition in Putin's Russia. Stanford: Stanford University Press.

Habermas, H. 2017. Strukturnoe izmenenie publichnoj sfery: Issledovaniya otnositel'no kategorii burzhuaznogo obshchestva. Moskva: Izdatel'stvo "Ves' Mir".

Harriss, J. 2010. "Participation" and Contestation in the Governance of Indian Cities. Simons Papers in Security and Development 3, https://summit.sfu.ca/item/14834 (accessed 22.06.2020).

Inglehart, R., Welzel, C. (eds.). 2005. Modernization, Cultural Change, and Democracy. The Human Development Sequence. Cambridge: Cambridge University Press.

Ionescu, G. 1966. Control and Contestation in Some One-Party States. Government and Opposition 1, pp. 240-250.

Jayasuriya, K., Rodan G. 2007. Beyond Hybrid Regimes: More Participation, Less Contestation in Southeast Asia. Democratization 14(5), pp. 773-794.

Jouvenel, B. 1966. The means of Contestation. Government and Opposition 1, pp. 155-174.

Katsaura, O. 2012. Community Governance in Urban South Africa: Spaces of Political Contestation and Coalition. Urban Forum 23(3), pp. 319-342.

Kertman, K., Miryasova, O. 2010. Ot obyvatelej k aktivistam. Zarozhdayushchiesya social'nye dvizheniya v sovremennoj Rossii. Moskva: Tri kvadrata. 
Kodeks Rossijskoj Federacii ob administrativnyh pravonarusheniyah, 2001. 195-FZ, http://www.consultant.ru/document/cons_doc_LAW_34661/(accessed 22.06.2020).

The Legacy of the Arab Spring. New Forces and Fault Lines. 2016. Revolutions 4, Issue 1.

McAdam, D., Tarrow, S., Tilly, C. 2001. Dynamics of Contention. Cambridge: Cambridge University Press.

Nisnevich, Y. 2011. Politiko-pravovoy analiz kak metod politicheskikh issledovaniy. Kontury global'nykh transformatsiy: politika, ekonomika, parvo 1, pp. 6-15.

Patrushev, S.W. (ed.). 2013. Grazhdanskoe i politicheskoe v rossijskih obshchestvennyh praktikah. Moskva: Rossijskaya politicheskaya enciklopediya (ROSSPEN).

Patrushev, S.W. (ed.). 2016. Massovaya politika: institucional'nye osnovaniya. Moskva: Politicheskaya enciklopediya.

Peticiya Prezidentu, https://петиция-президенту.pф (accessed 20.04.2020).

Pod'yachev, K., 2012. Protestnoe dvizhenie v Rossii "nulevyh": genezis i specifika. Vestnik instituta sociologii RAN 5, pp. 146-163.

Porshnev, A., Lyachina, K. 2018. Analiz dinamiki elektronnyh peticij na portale Rossijskaya obshchestvennaya iniciativa. Gosudarstvo i grazhdane v elektronnoj srede 2, pp. 118-125.

Postanovlenie Konstitucionnogo Suda RF, 2013, № 4-P “Po delu o proverke konstitucionnosti federal'nogo zakona $O$ vnesenii izmenenij $v$ Kodeks Rossijskoj Federacii ob administrativnyh pravonarusheniyah $i$ federal'nyj zakon $O$ sobraniyah, mitingah, demonstraciyah, shestviyah i piketirovaniyah v svyazi s zaprosom gruppy deputatov Gosudarstvennoj Dumy i zhaloboj grazhdanina E.V. Savenko”, http://www.consultant. ru/document/cons_doc_LAW_142234/(accessed 22.06.2020).

Protesty 23.01. Glavnoe, 2021. Kommersant. 23 January. https://www.kommersant.ru/ doc/4661089 (accessed 24.01.2021).

Putin podpisal zakon o "nezhelatel'nyh" organizaciyah. 2015. Informacionnoe agentstvo Rossii - TASS, http://tass.ru/politika/1990676 (accessed 22.06.2020).

Rossijskaya obshchestvennaya iniciativa, https://www.roi.ru/page/how-it-works/ (accessed 20.04.2020).

Rossiyanam otbili zhelanie mitingovat'. 2019. Kommersant, 2 December, https://www. kommersant.ru/doc/4179030 (accessed 22.06.2020).

Salenko, A. 2019. Svoboda mirnyh sobranij: “detskie mitingi” i "vzroslye sankcii”. Zhurnal rossijskogo prava 8, pp. 48-61.

Savenkov, R. 2019. Elektoral'nyj potencial oppozicionnyh kandidatov po itogam vyborov v regional'nye parlamenty v Central'no-Chernozemnom regione (2010-2018 gg.). Politicheskaya nauka 2, pp. 74-94.

Shul'man E. 2014. Surrogaty parlamentarizma. Pro et Contra 1-2, pp. 124-132.

Sztompka, P. 2012. Socjologia. Analiza społeczeństwa. Kraków: Wydawnictwo Znak.

Tilly, C., Tarrow, S. 2015. Contentious Politics. Oxford: Oxford University Press, Second Edition.

Timofeeva, L. 2020. Publichnaya kritika kak sredstvo preduprezhdeniya nasiliya v obshchestve. Politicheskaya nauka 3, pp. 114-146.

Trantidis, A. 2016. Is government contestability an integral part of the definition of democracy? Politics 37, pp. 67-81.

V. Putin uzhestochil nakazanie za besporyadki na mitingah, 2014. Rossijskaya gazeta. 22 July, http://www.rg.ru/2014/07/22/mitingi-anons.html, 29.09.2015 (accessed 22.06.2020). 
Van Vossole, J. 2015. Long waves of political contestation. Kondratieff Waves 2, pp. 276-297.

Vidyasova, L., Tensina, Y. 2017. Issledovanie rezul'tativnosti raboty portala "Rossijskaya obshchestvennaya iniciativa". Gosudarstvo i grazhdane $v$ elektronnoj srede 1, pp. 56-65.

Volkov, D. 2012. Protestnye mitingi v Rossii konca 2011-nachala 2012 gg.: zapros na demokratizaciyu politicheskih institutov. Vestnik obshchestvennogo mneniya 2, pp. 73-86.

Volodenkov, S. 2020. Transformaciya sovremennyh politicheskih processov v usloviyah cifrovizacii obshchestva: klyuchevye scenario. Kontury global'nyh transformacij: politika, ekonomika, parvo 13, 2, pp. 6-24.

Ya ne ponimayu, 2020. Kommersant, 17 June, https://www.kommersant.ru/doc/4380436 (accessed 22.06.2020).

Zhuvenel de, B. 2011. Vlast': Yestestvennaya istoriya yeyë vozrastaniya. Moskva: Mysl'. 